\title{
Infantilis haemangioma: klinikai és demográfiai jellemzők, kezelési-gondozási tapasztalatok
}

\author{
Csoma Zsanett Renáta dr. ${ }^{1}$. Dalmády Szandra dr. ${ }^{1}$. Ábrahám Rita dr. ${ }^{1}$ \\ Rózsa Tamás dr. ${ }^{1}$ - Rácz Katalin dr. ${ }^{2}$ - Kemény Lajos dr. ${ }^{1,3}$ \\ Szegedi Tudományegyetem, Általános Orvostudományi Kar, ${ }^{1}$ Bőrgyógyászati és Allergológiai Klinika, \\ ${ }^{2}$ Gyermekgyógyászati Klinika és Gyermekegészségügyi Központ, Szeged \\ ${ }^{3}$ Magyar Tudományos Akadémia-Szegedi Tudományegyetem Dermatológiai Kutatócsoport, Szeged
}

Bevezetés: Az infantilis haemangioma a leggyakoribb csecsemő- és kisdedkori vascularis tumor; speciális, különleges klinikai lefolyásának, magas spontán remissziós hajlamának köszönhetően általában nem igényel bőrgyógyászati kezelést. A tumorok 10-15\%-a azonban komoly szövődményeket okozhat, ezen utóbbi esetek speciális kezelést és szoros utánkövetést igényelnek.

Célkitüzés: A szerzők célkitűzése az volt, hogy négy és fél éves vizsgálati periódus során feldolgozzák a Szegedi Tudományegyetem Bőrgyógyászati és Allergológiai Klinikájának Gyermekbőrgyógyászati Szakrendelésén infantilis haemangioma miatt kezelt betegek adatait, és bemutassák a kezelést igénylő esetek kapcsán szerzett tapasztalataikat. Módszer: Részletesen vizsgálták a csecsemők demográfiai adatait (nem, gesztációs kor és gesztációs súly, perinatalis anamnézis, édesanya terhességi kórtörténete), az infantilis haemangioma miatt bőrgyógyászati szakrendelésen való megjelenés idejét, a tumorok számát, klinikai altípusát és anatómiai lokalizációját, a tumorokkal kapcsolatosan jelentkező szövődményeket. Ezt követően részletesen elemezték a kezelés módját, időtartamát, eredményességét és a gyógyszeres kezelés során fellépő mellékhatásokat.

Eredmények: A vizsgálati periódus alatt 96 gyermeket észleltek infantilis haemangioma diagnózissal összesen 163 tumorral. 54 esetben elegendő volt a rendszeres obszerváció, míg 42 gyermek esetén helyi vagy szisztémás béta-blokkoló kezelés beállítása volt indokolt. A kezelt csoportban valamennyi esetben a tumorok regressziója következett be, mellékhatás mindössze hat esetben jelentkezett. A béta-blokkoló kezelést igénylő gyermekek átlagos gesztációs kora és gesztációs súlya szignifikánsan alacsonyabb volt a kezelést nem igénylő gyermekekéhez képest.

Következtetések: A komplikált infantilis haemangiomák kezelésében jelenleg a szisztémás propranololkezelés az elsó vonalbeli terápia. Eredményeink egyértelmúen megerősítik a gyógyszer kiváló terápiás effektusát. Jelentős probléma, hogy a gyermekek sok esetben későn kerülnek a tumorok kezelésében jártas bőrgyógyászati centrumokba. A korai életkorban elkezdett terápia jelentősége hangsúlyozandó.

Orv Hetil. 2017; 158(39): 1535-1544.

Kulcsszavak: infantilis haemangioma, demográfiai adatok, tumorjellemzók, obszerváció, szisztémás propranololkezelés

\section{Infantile haemangioma: clinical and demographic characteristics, experiences in the treatment}

Introduction: Infantile haemangiomas are the most common vascular tumours of infancy. The vast majority of the lesions do not require dermatological treatment due to their unique clinical course and the high rate of spontaneous regression. Approximately 10-15\% of the tumours result in severe complications and sequale, requiring special management and close follow-up.

Aim: The aim of the present study was to assess the data of the patients treated with infantile haemangiomas, and to summarize the results of the therapy during 4.5 years of study period, in the Paediatric Dermatology Outpatient Clinic of the Department of Dermatology and Allergology, at the University of Szeged.

Method: Demographic data of the infants (gender, gestational age and weight, perinatal history of the infant and medical history of mothers), exact date of the visits at Paediatric Dermatology Outpatient Clinic and tumour characteristics (number, subtype, anatomical localisation and complications) were analysed in details. Treatment modalities and therapy intervals, outcomes and the adverse events of the therapies were also discussed in the survey. 
Results: During the study period, 96 infants with 163 infantile haemangiomas were observed. 54 patients required regular observations, while 42 infants required local or systemic beta-blocker therapy. All of the tumours treated with local or systemic therapy showed marked clinical regression; adverse effects were observed in only 6 cases. The gestational age and gestational weight of infants requiring beta-blocker therapy was significantly lower as compared to children needed only observation.

Conclusions: Systemic propranolol is currently the first-line treatment modality for complicated infantile haemangiomas. Our results confirm the significant therapeutic efficacy of propranolol. Early introduction of the treatment is relevant; unfortunately a great proportion of patients are referred late to Paediatric Dermatology Centres.

Keywords: infantile haemangioma, demographic data, tumour characteristics, observation, systemic propranolol treatment

Csoma Zs R, Dalmády Sz, Ábrahám R, Rózsa T, Rácz K, Kemény L. [Infantile haemangioma: clinical and demographic characteristics, experiences in the treatment]. Orv Hetil. 2017; 158(39): 1535-1544.

(Beérkezett: 2017. július 2.; elfogadva: 2017. július 30.)

\section{Rövidítések}

$\mathrm{IH}=$ infantilis haemangioma

Az infantilis haemangioma (IH) a leggyakrabban előforduló gyermekkori jóindulatú vascularis tumor: az érett újszülöttekben becsült prevalenciája $4,5 \%$ körül mozog $[1,2]$. A tumorok általában születéskor még nem láthatóak, az első-második élethéten (12. élethét előtt) alakulnak ki. Érdekesség azonban, hogy az esetek jelentős százalékában az újszülöttek alapos fizikális vizsgálata során úgynevezett haemangiomaprekurzor laesiókat találhatunk: teleangiectasiás, halvány vagy bevérzésszerű foltokat $[2,3]$. Epidemiológai vizsgálatok eredménye alapján az alábbi rizikófaktorok jelentősen növelik az IH előfordulási gyakoriságát: női nem (két-háromszoros rizikó), kaukázusi népcsoport, koraszülöttség, alacsony születési súly (figyelemre méltó adat: a testsúly 500 gként történő csökkenésével párhuzamosan 40\%-kal emelkedik az IH gyakorisága, 1000 g alatti koraszülöttekben a prevalencia $23 \%$ ), magasabb anyai életkor, többes terhesség, placentaanomáliák (placenta previa, abruptio placentae), chorioamnionitis, praeeclampsia, chorionboholy-biopszia, in vitro fertilizáció az édesanya anamnézisében $[1,2,4-10]$. A tumor patogenezisében fontos szerepet játszik az endothelialis progenitor sejtek szomatikus mutációja és a vascularis növekedési faktor szabályozási útvonal eltérése. A placentaris embolisatio hipotézise alapján az IH-t alkotó sejtek a méhlepényből származnak (azonos immunhisztokémiai markerek mutathatók ki a sejtek felszínén: GLUT-1, Lewis Y-antigén, FcyRII, merosin). A szöveti hypoxia az endothelialis progenitor sejtek és a vasculatura kifejezett proliferációját idézi elő; a csökkent szöveti oxigenizáció IH patogenezisében betöltött szerepét támasztja alá az a tény, hogy a tumorok lényegesen gyakrabban fordulnak elő kora- szülöttekben, magasabb anyai életkor és méhlepényrendellenességek fennállása esetén $[1,2,11,12]$.

Az IH-k növekedése nem lineáris: a korai proliferációs fázisban a tumorok gyors növekedést mutatnak (a legintenzívebb növekedés az első három hónapban, az ötödik-nyolcadik élethét között figyelhető meg, a tumorok 80\%-os növekedése erre az időszakra esik), ez a folyamat a következő, lassú növekedési fázisban (hat-kilenc hónap) mérséklődik. A növekedési fázist platófázis, majd évekig tartó lassú regressziós, involúciós fázis követi, a tumorok körülbelül 85-90\%-a kettő-hat éves életkorra regrediál $[1-3,10,11,13]$.

Az IH-k csoportosítása többféleképpen történhet. A superficialis IH-k vagy hétköznapi nevükön eperhaemangiomák (50-60\%) a dermis felső részére lokalizálódó tumorok, klinikailag élénkvörös színú, gyakran lobulált felszínú papulák, plakkok vagy csomók formájában jelentkeznek. A mély IH-k (15\%) a dermis mélyebb részében és a subcutisban helyezkednek el, a tumorok kevésbé jól körülírhatóak, felszínük kékeslila, teleangiectasiás. A kevert IH-k (25-35\%) superficialis és mély komponenssel egyaránt rendelkeznek. Másik felosztás alapján fokális $(67 \%)$, szegmentális (13\%), multifokális (4\%) és nem meghatározott $(16 \%)$ csoportokba sorolhatjuk a tumorokat $[2,14,15]$.

A diagnózis elsődlegesen a klinikai képen alapul, számos esetben azonban képalkotó vizsgálatok elvégzése szükséges (hasi ultrahangvizsgálat, Doppler-ultrahangvizsgálat, MRI, MR-angiográfia) elsődlegesen a társuló anomáliák, a visceralis érintettség kivizsgálása céljából. A periorbitalis tumorok esetén szemészeti szakvizsgálat szükséges, míg a légúti tumorok diagnosztizálása (laringoszkópia) és kezelése során elengedhetetlen a fülorr-gégészeti vizsgálat. A benignus vagy diffúz neonatalis haemangiomatosis esetén ötnél (újabb irodalmi adatok szerint tíznél) több, általában kisméretű cutan haemangioma figyelhető meg, ezekben az esetekben na- 
gyon fontos a visceralis, elsősorban a hepaticus érintettség vizsgálata.

Az IH-k elkülönítő kórismézésében vascularis malformatiók (vénás vagy lymphaticus rendellenességek) és számos tumorféleség jöhet szóba. A superficialis daganatok differenciáldiagnózisa kapcsán fontos megemlíteni az alábbi laesiókat: congenitalis haemangioma, pyogen granuloma, tufted angioma, kaposiform haemangioendothelioma, bacillaris angiomatosis. Mély IH-k esetén nasalis glioma, dermoid cysta, infantilis myofibromatosis, lipoma, lipoblastoma, plexiform neurofibroma, neuroblastoma, illetve különböző lágyrész-sarcomák, infantilis fibrosarcoma, rhabdomyosarcoma, dermatofibrosarcoma protuberans merülhetnek fel az elkülönítő diagnózis során.

Az IH-k speciális, különleges klinikai lefolyásának, magas spontán remissziós hajlamának köszönhetően általában nem igényelnek bőrgyógyászati kezelést. A tumorok 10-15\%-a azonban komoly szövődményeket okozhat: a nagyméretű, gyorsan növekedő laesiók kifekélyesedhetnek, vitális életfunkciókat és az érzékszervek múködését veszélyeztethetik, illetve maradandó funkcionális és esztétikai károsodást okozhatnak. Természetesen ezen utóbbi esetek speciális kezelést és szoros utánkövetést igényelnek.

Felmérésünk fő célkitűzése az volt, hogy feldolgozzuk a Szegedi Tudományegyetem Bőrgyógyászati és Allergológiai Klinikájának Gyermekbőrgyógyászati Osztályán IH miatt kezelt betegek adatait, és bemutassuk a kezelést igénylő esetek kapcsán szerzett tapasztalatainkat.

\section{Módszer}

Retrospektív felmérésünket a Szegedi Tudományegyetem, Bőrgyógyászati és Allergológiai Klinika Gyermekbőrgyógyászati Szakrendelésén végeztük, 2013. január 1. és 2017. május 31. között, a Szegedi Tudományegyetem Humán Orvosbiológiai Intézményi és Regionális Kutatásetikai Bizottságának engedélyével. Célkitűzésünk az volt, hogy áttekintsük ezen négy és fél éves periódus alatt az IH diagnózissal megjelent és gondozott betegek adatait. Részletesen vizsgáltuk a csecsemók demográfiai adatait (nem, gesztációs kor és gesztációs súly, perinatalis anamnézis, édesanya terhességi kórtörténete), az IH miatt bőrgyógyászati szakrendelésen való megjelenés idejét, a tumorok számát, klinikai altípusát és anatómiai lokalizációját, a tumorokkal kapcsolatosan jelentkező szövődményeket. Ezt követően részletesen elemeztük a kezelés módját, időtartamát, eredményességét és a gyógyszeres kezelés során fellépő mellékhatásokat.

A betegek adatait, illetve a javasolt terápiás módozatokra vonatkozó adatokat az E-Medsolution rendszerből gyưjtöttük ki, majd anonim módon, Excel-táblázatban került sor rögzítésükre. Az eloszlás vizsgálatához az egymintás Kolmogorov-Szmirnov-próbát használtuk. A statisztikai analízisekhez Student-féle t-próbát, MannWhitney-tesztet, Pearson-féle $\chi^{2}$-próbát, Fischer-féle egzakt tesztet és ANOVA-tesztet használtunk az SPSS 22.0 programcsomag segítségével. Az alkalmazott statisztikai próbák szignifikanciaszintje 0,05 volt.

\section{Eredmények}

Retrospektív vizsgálatunkban, a 2013. január l. és 2017. május 31. közötti 4,5 éves periódus során 96 gyermeket észleltünk IH diagnózissal (29 fiúgyermek és 67 leánygyermek, $1: 2,31)$, összesen 163 tumorral.

Átlagosan egy gyermeknél 1,7 tumor fordult elő; 70 gyermek egy darab, 16 gyermek két darab, öt gyermek három darab, míg egy-egy gyermek négy, öt, hat, illetve tíz darab tumorral rendelkezett. A legnagyobb számú tumor, 21 IH egy hat hónapos leánygyermek esetében fordult elő.

A tumorok anatómiai régió szerinti megoszlása a következő volt: az IH-k 38,0\%-a a törzs területén, 34,4\%-a a fej-nyaki régióban, $13,5 \%$-a az alsó végtagokon, 10,4\%-a a felső végtagokon, $3,1 \%-\mathrm{a}$ az anogenitalis régióban fordult elő, egy esetben észleltünk visceralis, hepaticus érintettséget. A fej-nyaki régióban lévő tumorok részletes

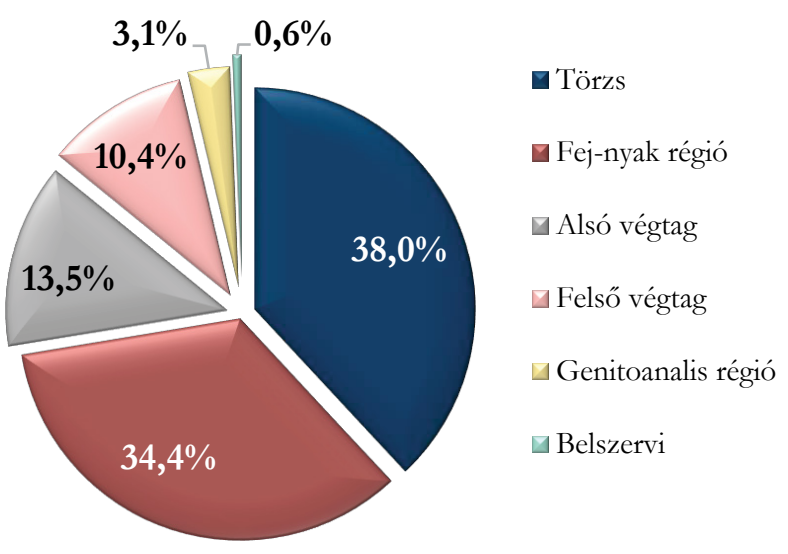

IA ábra $\quad$ Az infantilis haemangiomák anatómiai régió szerinti megoszlása $(\%)$

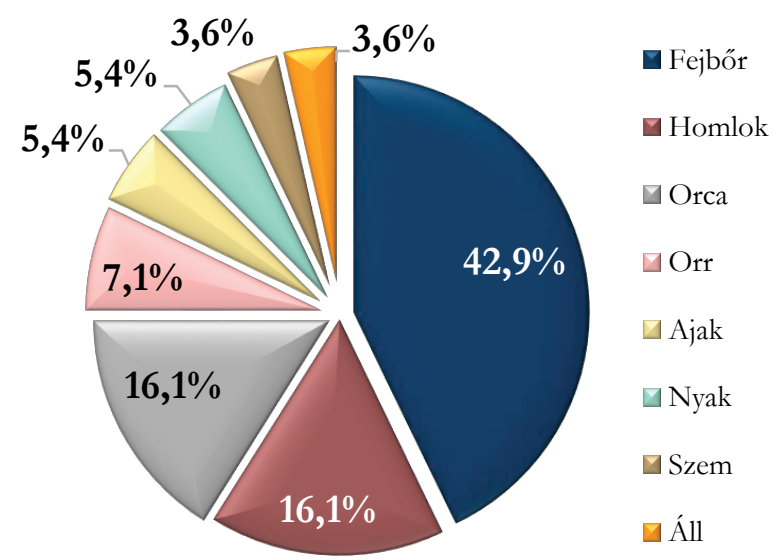

1B ábra | A fej-nyaki régióban lévő infantilis haemangiomák részletes megoszlása (\%) 

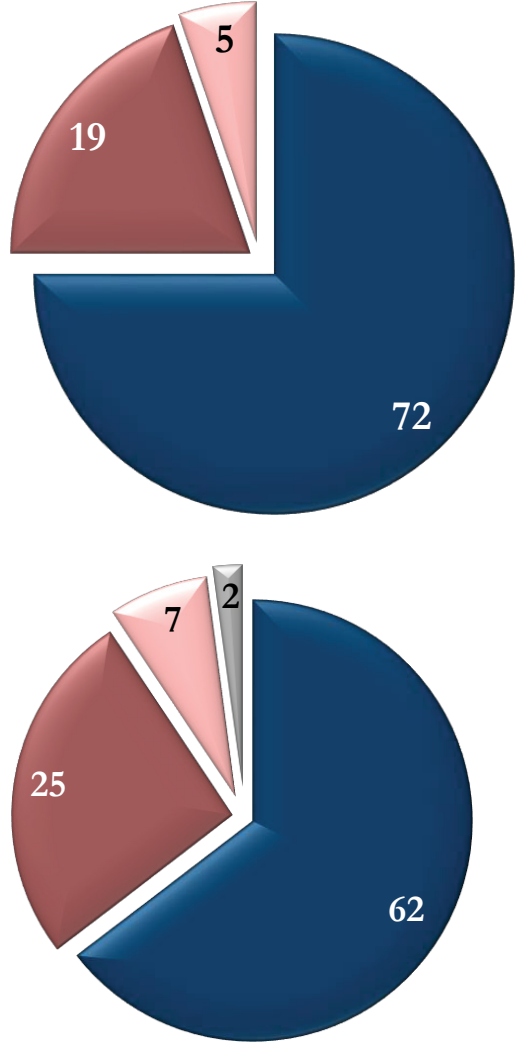

¿ Fokális

Multifokális

$\square$ Szegmentális

$\square$ Nem meghatározott

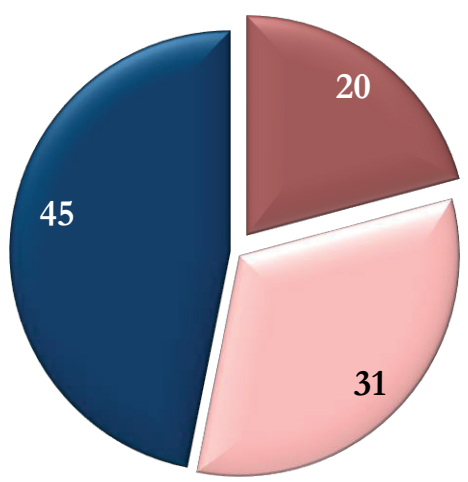

Magas rizikójú

$\square$ Intermedier rizikójú

- Alacsony rizikójú Az infantilis haemangiomák altípus szerinti csoportosítása (eset-
szám, $\mathrm{n}=96$ )

megoszlása a következő volt: fejbőr: 42,9\%, homlok $16,1 \%$, orca: $16,1 \%$, orr: $7,1 \%$, ajak: $5,4 \%$, nyak: $5,4 \%$, periorbitalis régió: $3,6 \%$, áll: 3,6\% ( $1 A$ és $1 B$ ábra).

$\mathrm{Az}$ IH altípus szerint megoszlása: fokális $(62$ fó, 64,6\%), multifokális (25 fó, 26,0\%), szegmentális (hét fó, $7,3 \%$ ), nem meghatározott (két fó, $2,1 \%$ ), míg a börben való elhelyezkedésük alapján superficialis (72 fó, 75,0\%), kevert (19 fó, 19,8\%), mély (öt fö, 5,2\%) volt. A szövődmények, komplikációk potenciális jelentkezése alapján alacsony rizikójú ( 45 fó, 46,9\%), intermedier rizikójú (31 fó, 32,3\%) és magas rizikójú (20f”o, 20,8\%) tumorokat különböztettünk meg $(2 A, 2 B, 2 C, 3$. és 4. ábra).

Haemangiomaprekurzor laesio 15 gyermek esetében szerepelt (egy esetben suffusiószerü laesio, 14 esetben

A

B

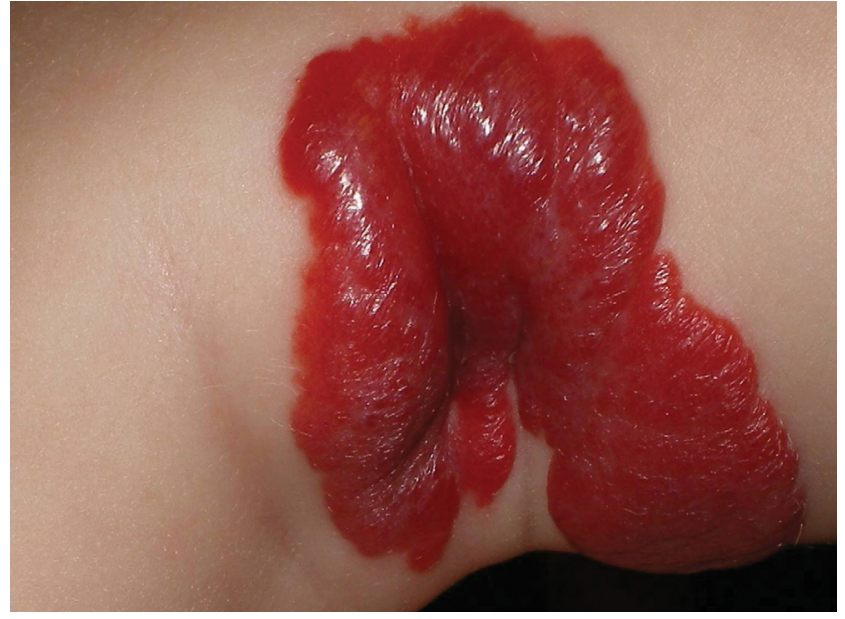

3. ábra $\quad$ Superficialis haemangioma a térdhajlat területén

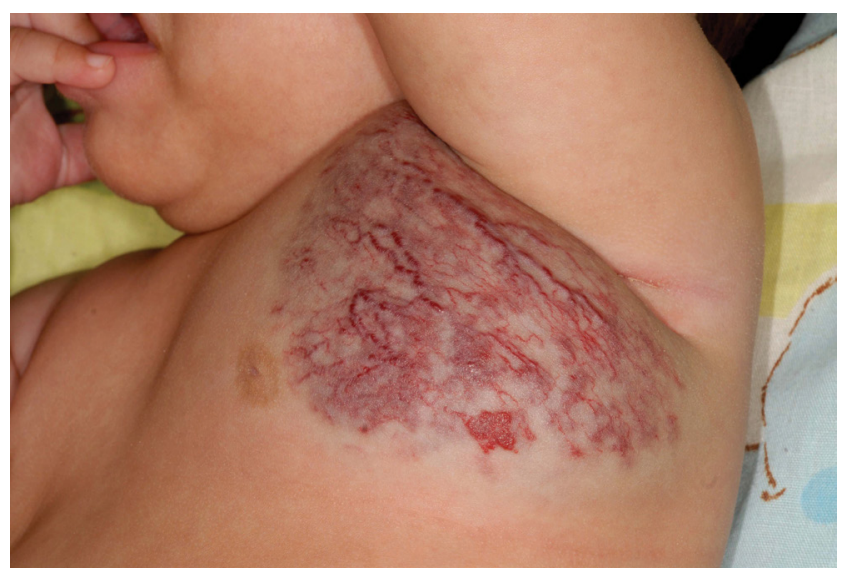

4. ábra | Mély infantilis haemangioma az axillaris régióban

teleangiectasiás macula) az újszülöttkori státuszban ( $5 \mathrm{~A}$ és $5 B$ ábra).

A teljes betegpopuláció átlagos gesztációs kora 36,56 \pm 3,92 hét (24-41 hét) volt, gesztációs kor szerinti részletes megoszlás a következő volt: három fő 24-27. hét, 10 fó 28-31. hét, 17 fő 32-36. hét, 63 fö $\geq 37$ hét. A csak obszervációt igénylő csoport átlagos gesztációs kora 37,48 $\pm 3,21$ hét, a kezelést igénylő betegeké 35,39 $\pm 4,43$ hét volt. A béta-blokkoló kezelést igénylő gyermekek átlagos gesztációs kora szignifikánsan alacsonyabb volt a kezelést nem igénylő gyermekekéhez képest ( $\mathrm{p}=$ 0,010) (1. táblázat).

A teljes betegpopulációt vizsgálva az átlagos születési súly $2806,61 \pm 859,49(700-4310 \mathrm{~g})$ gramm volt. Az obszervációt igénylő csoportban ennek értéke 3057,5 \pm 768,32 gramm, míg a kezelést igénylő betegcsoportban $2488,42 \pm 872,24$ gramm volt. A béta-blokkoló kezelést igénylő csecsemók születési súlya szignifikánsan alacsonyabb volt a kezelést nem igénylő gyermekekéhez képest $(\mathrm{p}=0,001)$ (1. táblázat).

A születési súly szerinti részletes megoszlás a következőképpen alakult: normális születési súly (2500-4000 g): 66 fó, alacsony születési súly (1500-2499 g): 14 fó, 


\begin{tabular}{lllll}
\hline Demográfiai jellemző & Összes beteg & $\begin{array}{l}\text { Kezelést nem igénylő } \\
\text { betegek }\end{array}$ & $\begin{array}{l}\text { Kezelést igénylő } \\
\text { betegek }\end{array}$ & p-érték \\
\hline Átlagéletkor az első észleléskor (hét) & $28,52 \pm 23,07$ & $32,50 \pm 23,21$ & $23,27 \pm 22,08$ & $\mathbf{0 , 0 1 7}^{*}$ \\
\hline Átlagos gesztációs kor (hét) & $36,56 \pm 3,92$ & $37,48 \pm 3,21$ & $35,39 \pm 4,43$ & $0,010^{*}$ \\
\hline Átlagos gesztációs súly (gramm) & $2806,61 \pm 859,49$ & $3057,50 \pm 768,32$ & $2488,415 \pm 872,24$ & $0,001^{*}$ \\
\hline Átlagos Apgar-érték a születést követő első percben & $8,31 \pm 2,04$ & $8,6 \pm 1,84$ & $7,89 \pm 2,25$ & 0,110 \\
\hline Császármetszés (\%) & 56,7 & 52,9 & 61,5 & 0,415 \\
\hline Intenzív osztályos ellátást igénylő betegek (\%) & 22,9 & 13,0 & 35,7 & $0,009^{*}$ \\
\hline
\end{tabular}

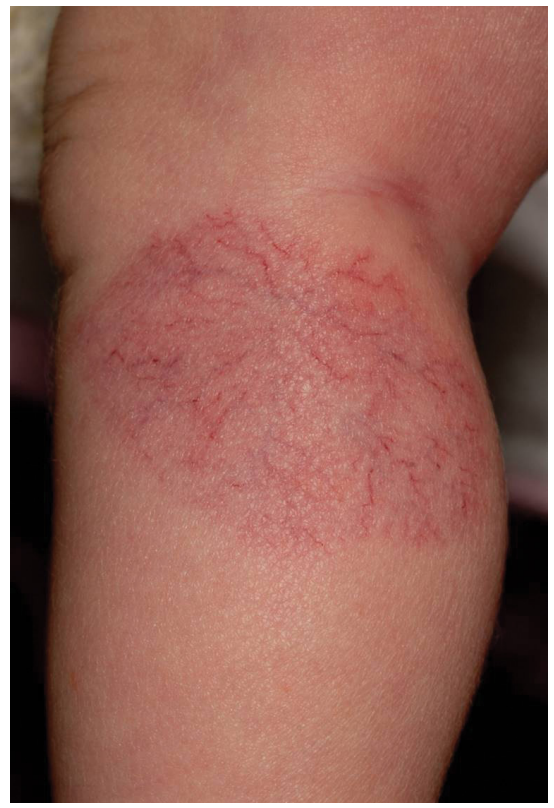

$5 \mathrm{~A}$ ábra

Az újszülött leánygyermek lábszárának hátulsó felszínén livid, teleangiectasiás folt, haemangiomaprekurzor laesio észlelhető

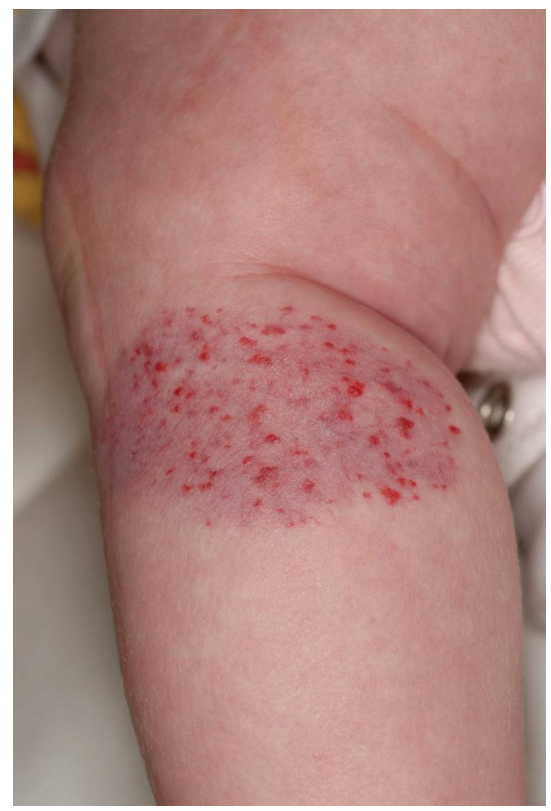

5B ábra

A folt területén négy héttel később számos apró, erythemás papula kialakulása figyelhető meg igen alacsony születési súly (1000-1499 g): kilenc fó, extrém alacsony születési súly ( $<1000 \mathrm{~g})$ : négy fó.

A teljes betegpopulációt vizsgálva a gyermekek $22,9 \%$-a igényelt intenzív osztályos ellátást a születést követően; az intenzív osztályos gondozás gyakorisága a kezelést igénylő csoportban $35,7 \%$, az obszervációt igénylő csoportban $13,0 \%$ volt. A béta-blokkoló kezelést igénylő csecsemők újszülöttkori anamnézisében szignifikánsan gyakrabban szerepelt intenzív osztályos ellátás $(\mathrm{p}=$ 0,009) (1. táblázat).

A gyermekek $56,7 \%$-a császármetszéssel jött világra a teljes betegpopulációban; a sectio caesarea aránya a két csoportban (obszerváció vs. kezelt csoport) 52,9 , illetve $61,5 \%$ volt. A két csoport között nem volt szignifikáns különbség a születés módját illetően (1. táblázat).

Az édesanyák anamnézisében a következő betegségek fordultak eló: hypertonia négy, gesztációs vagy l-es típusú diabetes mellitus kilenc, méhlepény-rendellenesség öt esetben. Az anyai betegségek előfordulása nem mutatott szignifikáns különbséget a kezelést igénylő/nem igénylő csoportot tekintve $(\mathrm{p}=0,947)$.

A tumorok első észlelésekor a gyermekek átlagéletkora $28,52 \pm 23,07$ hét volt; ennek értéke a csak obszervációt igénylő csoportban $32,5 \pm 23,2$ hét, a kezelést igénylő csoportban 23,27 $\pm 22,08$ hét volt. Látható, hogy a bé-

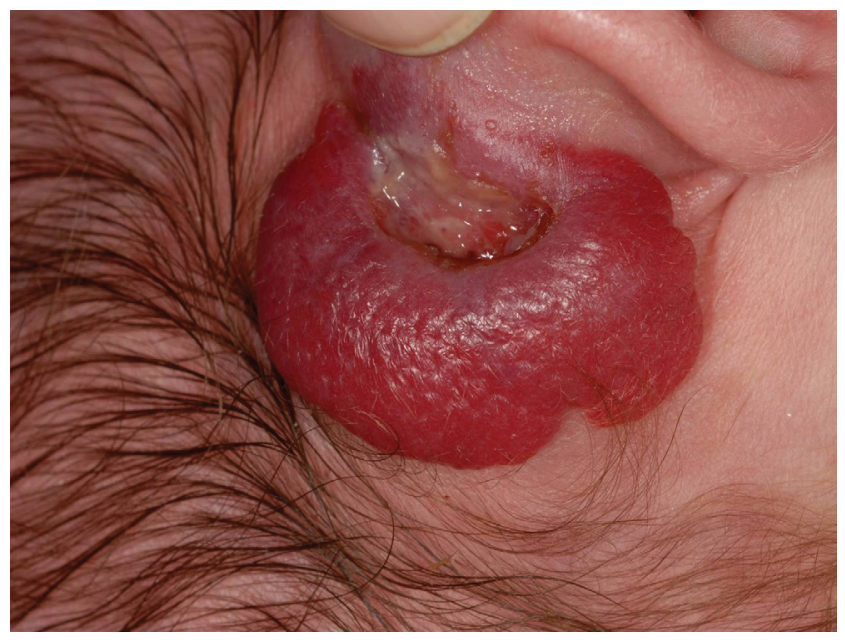

6. ábra | Kifekélyesedő haemangioma a fül mögött 
ta-blokkoló kezelést igénylő csecsemők szignifikánsan fiatalabb korban kerültek el bőrgyógyász szakorvoshoz $(\mathrm{p}=0,017)$ (1. táblázat).

Kifekélyesedő IH kilenc gyermek esetében volt jelen (9,37\%) (6. ábra), ebből hat esetben indikáltunk gyógyszeres kezelést (három esetben propanolol-, egy esetben lokális timolol-, két esetben szisztémás propranolol- és lokális timololkezelést). A kifekélyesedő haemangiomák közül ötöt-ötöt a fej-nyak régió, egyet a felső végtag, egyet az alsó végtag, egyet a törzs, egyet pedig az anogenitalis régió területén észleltünk.

Rendszeres obszervációt 54 esetben (33 leánynál és 21 fiúnál) elegendőnek tartottunk, míg 42 gyermeknél (34 leány és nyolc fiú) helyi vagy szisztémás béta-blokkoló kezelés beállítását tartottuk indokoltnak. A kezelést igénylő csoportban szignifikánsan magasabb volt a leánygyermekek aránya $(\mathrm{p}=0,036)$. Propranololkezelést 22 beteg kapott, ebből öt a propranolol mellett helyi timololgél-kezelésben is részesült. Lokális timololkezelést csak 15 gyermek kapott. A szisztémás propranololkezelés átlagos időtartama 27,73 $\pm 21,31$ hét, a lokális kezelés átlagos időtartama 36,09 $\pm 17,10$ hét, míg a propranolol és timolol együttes vagy egymás utáni alkalmazása esetén az átlagos kezelési idő 57,2 \pm 48,79 hét volt. A kezelést igénylő esetek $72 \%$-ában teljes vagy jelentős fokú, 28\%-ában mérsékelt fokú regressziót tapasztaltunk (7. és 8 . ábra). A kezelés során hat gyermeknél észleltük mellékhatás jelentkezését: éjszakai nyugtalanság, alvászavar három fơnél, enyhe fokú bradycardia, collapsus, obstruktív bronchitis egy-egy fönél jelentkezett.

\section{Megbeszélés}

Az IH igen különleges és viszonylag gyakori gyermekkori jóindulatú daganat. A tumorok újszülött- és csecsemőkorban jelennek meg, egyedülálló klinikai lefolyásukat növekedési és involúciós fázis jellemzi. Kifejezett regressziós hajlamuknak köszönhetően kezelésükben az úgynevezett aktív, intervenció nélküli terápiát tekintjük aranystandardnak [3]. Ennek lényeges eleme a csecsemő rendszeres kontrollja, obszervációja, a tumor státuszának precíz rögzítése, fotódokumentációja, és természetesen kiemelt hangsúlyt kap a szülők tájékoztatása, edukációja.

A gyermekek 10-15\%-ában azonban a vitális funkciókat, az érzékszervek fejlődését és múködését veszélyeztető, maradandó funkcionális és esztétikai károsodást, deformitást okozó tumorok kerülnek diagnosztizálásra; ezekben az esetekben a korai, adekvát terápia kiemelt fontosságú.

A kezelést igénylő tumorok mintegy 15-25\%-ában fordul elő kifekélyesedés a tumor rapid növekedési fázisában (négy-hat hónapos kor között): leggyakrabban az alsó ajak, a nyak, az anogenitalis és az intertriginosus régiók területén. A nagyméretű, a szegmentális, a superficialis és a kevert IH-k gyakrabban ulcerálódnak.
Az exulceratio mellett gyakran fájdalom, vérzés, felülfertőzés komplikálja a klinikai képet, jelentősen rontva a kis betegek életminőségét $[1,3,11,16]$.

$\mathrm{Az}$ anatómiai lokalizáció függvényében számos esetben okozhatnak funkcionális károsodást a tumorok. Így a periocularis IH-k látászavart, amblyopiát, asztigmatizmust, strabismust, exophthalmust, ptosist, proptosist, a szemgolyó dislocatióját, az ajak tumorai táplálási nehezítettséget, a nyak, az úgynevezett szakállrégió, a subglotticus-paraglotticus régió tumorai, az intratrachealis IH-k, valamint az orr környéki tumorok légzési nehezítettséget, obstrukciót, a nyaki régió nagy tumorai torticollist idézhetnek elő. A mell (emlőbimbó körül, areola) területén kialakult mély vagy kevert IH-k az emlő hypoplasiáját idézhetik elő, emiatt kezelést igényelnek. Kozmetikai, esztétikai problémákat elsősorban az arc nagy IH-i okozhatnak [1, 3, 17]. Fontos hangsúlyozni, hogy a daganatok az esetek mintegy 50-70\%-ában residualis laesio hátrahagyásával gyógyulnak: heg, anetoderma, fibroticus szövetmassza, erythema, teleangiectasia, atrophia, hipopigmentáció jelezheti a regrediált tumorokat $[1,3,11,16]$.

Az esetleges szövődmények és a kezelési indikáció felméréséhez számos pontrendszer, skála áll rendelkezésre a szakirodalomban: Haemangioma Severity Scale, Haemangioma Dynamic Complication Scale, Haemangioma Activity Score, Haemangioma Investigator Group Research Score; az alábbi szempontok értékelése történik meg: tumor legnagyobb átmérője, anatómiai lokalizáció, szövődmények, komplikációk megléte, kozmetikai diszfiguráció valószínúsége $[1,18,19]$.

Felmérésünkben a Gyermekbőrgyógyászati Szakrendelésen IH diagnózissal gondozásba vett gyermekek adatait dolgoztuk fel. Vizsgálatunk négy és fél éves időszaka alatt 96 betegnél összesen 163 IH-t diagnosztizáltunk. Kifekélyesedés kilenc, vérzés öt esetben fordult elő. A tumorok 34,4\%-a a fej-nyaki régióban alakult ki, tíz gyermek esetében nagyméretű, az arc centrális részére lokalizálódó tumor állt fenn. Összesen a gyermekek $32,6 \%$-át soroltuk intermedier, 18,5\%-át magas rizikójú csoportba a potenciális szövődmények kialakulása szempontjából.

A korábbi epidemiológiai vizsgálatok számos rizikófaktort azonosítottak a tumorok kialakulása szempontjából, ezek közül igen fontos, hogy az IH-k lényegesen gyakrabban fordulnak elő koraszülöttekben [4-6, 8, 9, 13-15]. Ennek megfelelően betegeink kétharmada koraszülött volt, a 37. gesztációs hét előtt jött világra, illetve az újszülöttek egyharmadának születési súlya $2500 \mathrm{~g}$ alatt volt. Figyelemre méltó, hogy a komplikált, kezelést igénylő tumorokkal rendelkező csecsemők gesztációs kora és súlya szignifikánsan alacsonyabb volt a csak obszervációt igénylő betegcsoporthoz képest, illetve a béta-blokkoló kezelésben részesült gyermekek nagyobb hányada igényelt intenzív terápiás ellátást élete első időszakában. Ezek a tényezők természetesen szorosan korrelálnak egymással. 

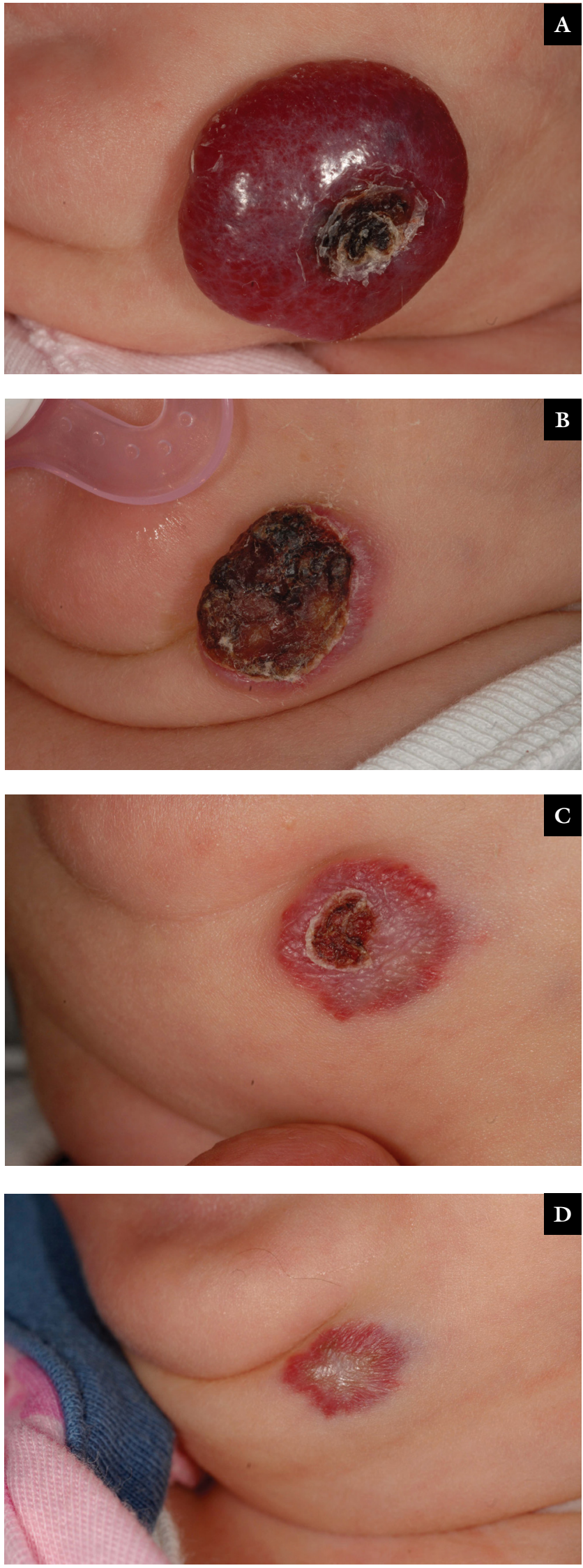

7. ábra

Az áll területén lévő nagyméretű, kifekélyesedő haemangioma szisztémás propranololkezelés bevezetése előtt (A), illetve egy hónap (B), két hónap (C) és három hónap (D) múlva
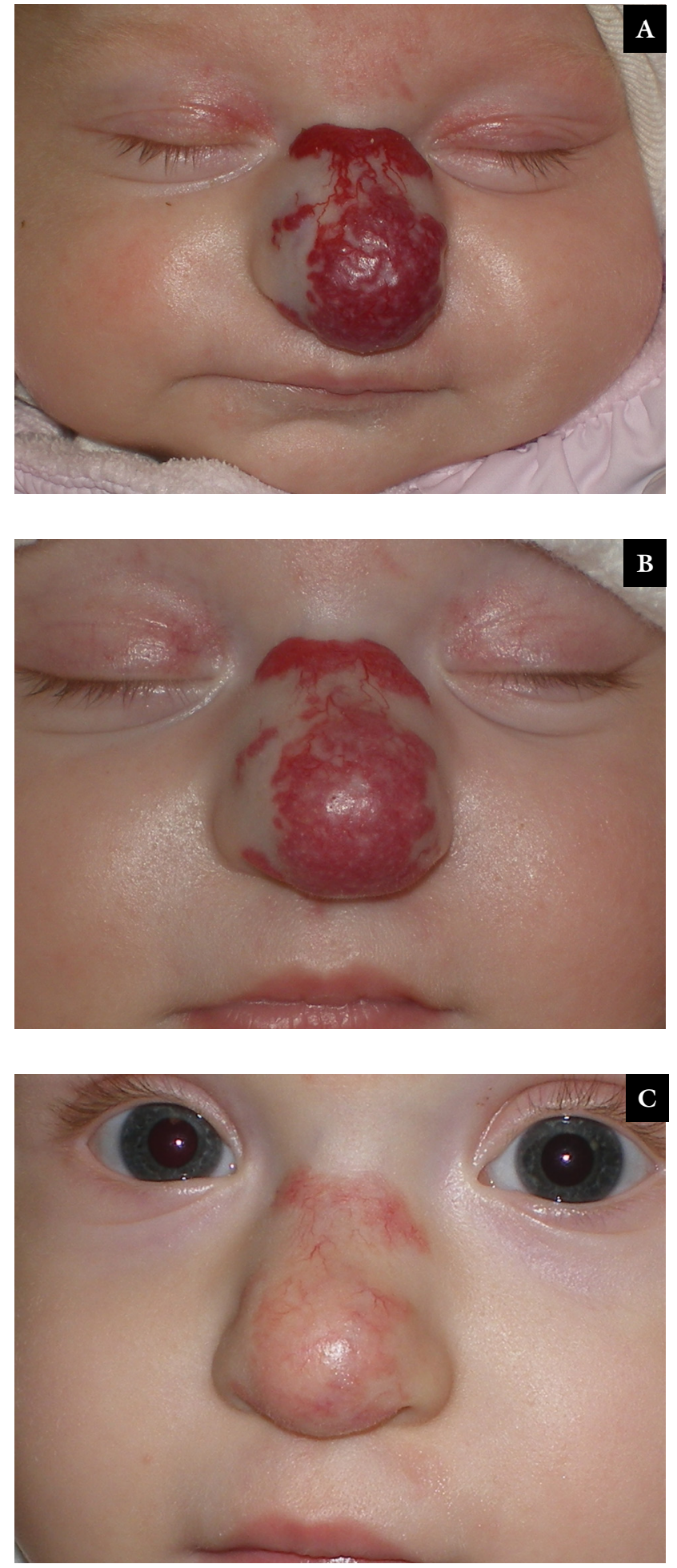

8. ábra

Orron lévő IH („Cyrano-orr”) a szisztémás propranololkezelés bevezetése előtt (A), egy hónap (B) és öt hónap (C) múlva

Az IH kezelésében alapvetően gyógyszeres, lézeres és sebészeti terápiás módozatok állnak rendelkezésre. Hosszú éveken, évtizedeken keresztül első vonalbeli kezelés a szisztémás kortikoszteroidterápia volt, illetve a szteroidterápia hatástalansága esetén vincristin- és interferonkezelés alkalmazása [2]. A jelentkező súlyos sziszté- 
más mellékhatások azonban sok esetben jelentős korlátot szabtak a kezelésnek.

A gyógyszeres kezelésben drámai korszakváltást jelentett a lokális és szisztémás béta-blokkoló terápia bevezetése. Az élettudományok területén számos nagy felfedezés a véletlennek köszönhető: a bordeaux-i egyetemi kórház bőrgyógyász szakorvosa, Dr. Christine LéautéLabrèze figyelte meg elsőként a propranololterápia hatékonyágát a komplikált IH-k kezelésében 2008-ban [20]. Hatékonyságát napjainkra már több száz klinikai vizsgálat igazolja: a randomizált, placebokontrollált klinikai vizsgálatok és metaanalízisek alapján az IH-k 96-98\%-a regressziót mutat hat hónapos gyógyszeres kezelést követően; a propranolol szignifikánsan hatékonyabb terápiának bizonyult a szisztémás szteroidkezeléshez képest [10, 21-23]. Magyarországon 2009 óta alkalmazzák a szisztémás és lokális béta-blokkoló kezelést az IH-k terápiájában; a nemzetközi adatokhoz hasonlóan valamennyi munkacsoport a gyógyszer kimagasló terápiás effektusáról számolt be [24-26].

A propranolol a nem szelektív béta-receptor-blokkolók (béta-1 és béta-2 adrenerg) családjába tartozó „régiúj" gyógyszer: több évtizedes tapasztalat áll rendelkezésre gyermekkardiológiai javallatban (arrhythmiák, hypertensio, hypertrophiás cardiomyopathia) történő alkalmazásával kapcsolatban. Már az első esetleírások során megfigyelték, hogy a gyógyszer hatására a tumor színe és konzisztenciája gyorsan változik, ez a jelenség a propranolol vasonconstrictiv hatásának köszönhető [20, 27]. Emellett a vascularis endothelialis növekedési faktor útvonal, a GLUT-1-receptorok és a renin-angiotenzin rendszer gátlása, valamint az endothelialis sejtek apoptózisának indukciója is lényeges szerepet játszik a gyógyszer hatásmechanizmusában [1, 2, 17, 27].

Magyarországon és az Európai Unió összes tagállamában 2014. április 23. óta a Hemangiol 3,75 mg/ml belsóleges oldat (Pierre Fabre Dermatologie) forgalomba hozatali engedéllyel rendelkezik, így az alkalmazási előírásban szereplő indikációban hivatalosan (nem „off-label”) rendelhető. Amennyiben a propranolol osztott por formájában kerül alkalmazásra, „off-label” kezelésnek minősül, emiatt a kezeléshez az Országos Gyógyszerészeti Intézet engedélye szükséges.

Nemzetközi irodalmi adatok és konszenzusriportok alapján az IH kezelésében a propranolol ajánlott terápiás dózisa 2-3 mg/ttkg/nap, napi két-három részre osztva, átlagosan hat hónapos kezelési időszakban $[2,3,11,17$, 21, 28]. A gyógyszer bevezetése kórházi körülmények között történjen az alábbi esetekben: nyolchetes kor (korrigált kor) vagy 3,5 kg-os testsúly alatt, légúti obstrukciót okozó tumorok (subglotticus haemangioma) esetén, szignifikáns szív-ér rendszeri, légzőszervi, illetve anyagcsere-betegségek (vércukorszint-eltérések, hypoglykaemiára való hajlam) fennállása esetén, belszervi eltérésekkel és anomáliákkal, szindrómákkal társuló IH esetén (PHACE-, LUMBAR-, SACRAL-, PELVICszindróma), emellett kórházi felvétel ajánlott nem meg- felelő szociális hátterü csecsemők esetében is $[3,17]$. A propranolol kezdő dózisa $0,5-1 \mathrm{mg} / \mathrm{ttkg} / \mathrm{nap}$, ezt követően fokozatosan emelhetjük a gyógyszer mennyiségét. Az első gyógyszeradag és az első emelt dózisú gyógyszer bevétele előtt, majd a bevételt követően egy és két óra múlva szükséges a gyermek vérnyomásának és pulzusának monitorizálása. Jó általános állapotú, megfelelő súlyú csecsemők esetében a béta-blokkoló kezelés ambuláns módon történő bevezetése is lehetséges. A gyermek ellenőrzése egy-két havonta mindenképpen javasolt, a gyógyszer adagját a gyermek testsúlyának növekedésével párhuzamosan kell növelni $[3,11,17,28]$.

PHACE-szindróma fennállása esetén, alacsony súlyú újszülöttek-csecsemők esetében, illetve a béta-blokkoló kezelés mellékhatásainak fellépése szempontjából fokozott rizikójú gyermeknél lényeges, hogy a kezelés szoros követés, monitorizálás mellett történjen: a propranololkezelést alacsony dózisban kezdjük el, a gyógyszer dózisát lassan, fokozatosan emeljük, a gyógyszer adagját napi három részre osszuk szét $[2,11,17]$.

A gyógyszeres kezelés optimális időtartama hat hónap; természetesen azonban indokolt esetben ennél hosszabb kezelési periódus is szükséges lehet (a relapsusráta hat hónapos kezelési idő mellett 17-20\%, egyéves kezelési időszak esetén csupán 5\%). A gyógyszeres kezelés befejezése előtt nem szükséges a gyógyszer dózisának fokozatos csökkentése.

$\mathrm{Az}$ alábbi állapotokban kontraindikált a propranololkezelés alkalmazása: sinusbradycardia, sick sinus szindróma, cardiogen sokk, hypotensio, II-III. fokú AV-blokk, szívelégtelenség, asthma bronchiale, a gyógyszerre való túlérzékenység, phaeochromocytoma, súlyos anyagcsere-betegségek, amelyek kifejezett hypoglykaemiával társulnak, gyógyszer-interakciók (például: kalciumcsatornablokkolók, antiarrhythmiás gyógyszerek, digitalis glycosidok, fenobarbitál stb.) [11, 17]. Propranololkezelés során jelentkező mellékhatások: hypotensio, bradycardia, bronchospasmus, hypoglykaemia, hyperkalaemia, alvászavar, zavartság, székrekedés, hasmenés [17, 21]. Táplálási nehezítettség, gastrointestinalis betegségek, hasmenés, hányás, obstruktív bronchitis esetén a gyógyszeres kezelés átmeneti felfüggesztése javasolt [11].

Kisméretü, lokalizált, superficialis IH kezelésére a korai növekedési fázisban elsődlegesen lokális béta-blokkoló készítmény, a timololgél $(0,1-0,25-0,5 \%$-os) és a propranololkrém (1-3\%-os) alkalmazását javasolhatjuk. A lokális kezelés jól tolerálható, hatékonysága $80 \%$ körül van. A szisztémás mellékhatások nagyon ritkán fordulnak elő, helyi mellékhatások közül erythema és pruritus alakulhat ki. Saját beteganyagunkban a $0,5 \%$-os timololgél és 1\%-os propranololkrém használata mellett sem szisztémás, sem lokális mellékhatást nem tapasztaltunk. Jelentős probléma azonban, hogy egyelőre standardizált készítmények nem állnak rendelkezésre a gyógyszertári forgalomban $[1,10,11,29]$.

A szakrendelésünkön megjelent betegek 44\%-ánál indikáltunk gyógyszeres kezelést: 15 betegnél lokális, 22 
betegnél szisztémás béta-blokkoló kezelést, öt esetben pedig mind lokális, mind szisztémás kezelés alkalmazásra került. (A magas kezelési arány annak köszönhető, hogy klinikánkra elsődlegesen a komplikált tumorokkal, nagyméretű IH-val rendelkező gyermekeket utalják be.) Az átlagos kezelési idő 35,45 hét volt, ennek értéke lokális kezelés esetén 36,09 hét, szisztémás kezelés esetén 27,73 hét volt. Valamennyi esetben megfigyelhető volt a tumorok regressziója, a kezelt betegek $72 \%$-ában jelentős fokú, 28\%-ában mérsékelt fokú regressziót észleltünk a kezelési periódus során. Hat betegnél jelentkezett mellékhatás: két esetben a kezelés átmeneti felfüggesztése, két esetben a propranolol dózisának csökkentése volt szükséges; a terápia végleges leállítására egy esetben sem került sor.

A terápiás válaszkészséget jelentősen befolyásolja a beteg életkora és a tumor növekedési kinetikája: a sikeres kezeléshez elengedhetetlen a korai életkorban, a tumor rapid növekedési fázisában elkezdett terápia. Természetesen a kezelési idószak során nagyon fontos a tumorok rendszeres fotódokumentációja: az objektív orvosi értékelés mellett a szülők megnyugtatásában is jelentős segítséget nyújthat.

Figyelemre méltó adat, hogy az első szakorvosi vizsgálat során a gyermekek átlagéletkora 28,52 $\pm 23,07$ hét volt, a kezelést igénylő betegek esetében ennek értéke $23,3 \pm 22,08$ hét, míg az obszervációs csoportban 32,3 $\pm 23,2$ hét volt. Az alapellátásban részt vevő védőnők és házi gyermekorvos kollégák szerepe kiemelkedően fontos a tumorok korai felismerésében. Irodalmi adatok szerint az IH esetében az újszülöttek jelentős részében haemangiomaprekurzor laesio előzi meg a tumor kialakulását $[13,15,30]$. Vizsgálatunkban a gyermekek 17,2\%-ában találtunk az újszülöttosztályról származó zárójelentésben IH-megelőző laesiókat, köszönhetően a neonatológus kollégák precíz státuszrögzítésének.

\section{Következtetések}

Az elmúlt évtized egyik legjelentősebb gyermek-bőrgyógyászati felfedezéseként tarthatjuk számon a béta-blokkoló kezelés hatékonyságának felismerését az IH-k kezelésében. A korábbi gyógyszeres kezelések alkalmazásának jelentôs gátat szabott a számos szisztémás mellékhatás fellépése ebben az amúgy is igen vulnerábilis betegcsoportban.

A propranolol mára a kezelést igénylő IH-k első vonalbeli, széles körben alkalmazott terápiás módozatává lépett elő: hatékonyságát és biztonságosságát számos klinikai tanulmány megerősítette. Természetesen nem egyszerű feladat a kezelés szükségességéről nyilatkozni: az esetek egy részében eldönthető a csecsemő első észlelésekor, sok esetben azonban a kezelési indikációt csak a tumor obszervációja során tudjuk felállítani.

A tumorok követése és kezelése multidiszciplináris szemléletet igényel, emiatt a betegek gondozását erre szakosodott és megfelelő jártassággal rendelkező centru- mokban ajánlott elvégezni. Az ideális eredmény eléréséhez nagyon fontos, hogy a csecsemók kezelését minél korábbi időpontban kezdjük el. Igen fontos és hangsúlyozandó feladat ezért az újszülöttek-csecsemők alapellátásában dolgozó szakorvos kollégák tájékoztatása és bevonása is.

Anyagi támogatás: A közlemény az „Intelligens élettudományi technológiák, módszertanok, alkalmazások fejlesztése és innovatív folyamatok, szolgáltatások kialakítása a szegedi tudásbázisra építve" címú EFOP-3.6.1-162016-00008 azonosítóval rendelkező pályázaton belül a „Multidiszciplináris egészségügyi, egészségnevelési és egészségfejlesztési összefogás az egészséges gyermekvállalásért és az egészséges gyermekek megszületéséért a Dél-Alföldi Régióban” alprojekt támogatásával jött létre.

Szerzôi munkamegosztás: Cs. Zs. R.: A vizsgálat koncepciójának kidolgozása, a betegek adatainak feldolgozása és elemzése, az irodalmi adatok áttekintése, a kézirat megírása. D. Sz.: A betegek adatainak feldolgozása és elemzése. Á. R.: A betegek adatainak feldolgozása és elemzése, a kézirat megírása. R. T.: Az irodalmi adatok áttekintése. R. K., K. L.: A kézirat átolvasása, bírálata, javítása. A cikk végleges változatát valamennyi szerző elolvasta és jóváhagyta.

Érdekeltségek: A szerzőknek nincsenek érdekeltségeik.

\section{Köszönetnyilvánítás}

Dr. Csoma Zsanett Renáta a Magyar Tudományos Akadémia Bolyai János Kutatási Ösztöndíjában részesül (2015-2018).

\section{Irodalom}

[1] Léauté-Labrèze C, Harper JI, Hoeger PH. Infantile haemangioma. Lancet 2017; 390: 85-94.

[2] Chen TS, Eichenfield LF, Friedlander SF. Infantile hemangiomas: an update on pathogenesis and therapy. Pediatrics 2013; 131: 99-108.

[3] Luu M, Frieden IJ. Haemangioma: clinical course, complications and management. Br J Dermatol. 2013; 169: 20-30.

[4] Dickison P, Christou E, Wargon O. A prospective study of infantile hemangiomas with a focus on incidence and risk factors. Pediatr Dermatol. 2011; 28: 663-669.

[5] Munden A, Butschek R, Tom WL, et al. Prospective study of infantile haemangiomas: incidence, clinical characteristics and association with placental anomalies. Br J Dermatol. 2014; 170: 907-913.

[6] Hoornweg MJ, Smeulders MJ, Ubbink DT, et al. The prevalence and risk factors of infantile haemangiomas: a case-control study in the Dutch population. Paediatr Perinat Epidemiol. 2012; 26: 156-162.

[7] Haggstrom AN, Drolet BA, Baselga E, et al. Prospective study of infantile hemangiomas: clinical characteristics predicting complications and treatment. Pediatrics 2006; 118: 882-887.

[8] Drolet BA, Swanson EA, Frieden IJ. Infantile hemangiomas: an emerging health issue linked to an increased rate of low birth weight infants. J Pediatr. 2008; 153: 712-715. 
[9] Chen XD, Ma G, Chen H, et al. Maternal and perinatal risk factors for infantile hemangioma: a case-control study. Pediatr Dermatol. 2013; 30: 457-461.

[10] Goelz R, Poets CF. Incidence and treatment of infantile haemangioma in preterm infants. Arch Dis. Child Fetal Neonatal Ed. 2015; 100: F85-F91.

[11] Hoeger PH, Harper JI, Baselga E, et al. Treatment of infantile haemangiomas: recommendations of a European expert group. Eur J Pediatr. 2015; 174: 855-865.

[12] Itinteang T, Withers AH, Davis PF, et al. Biology of infantile hemangioma. Front Surg. 2014; 1: 38.

[13] Eichenfield LF, Frieden IJ. (eds.) Neonatal and infant dermatology. 3rd ed. Elsevier Saunders, 2015.

[14] Bolognia JL, Jorizzo JL, Schaffer JV. (eds.) Dermatology, 2-Volume Set. 3rd ed. Elsevier Saunders, 2012.

[15] Paller A, Mancini A. (eds.) Hurwitz clinical pediatric dermatology. 4th ed. Elsevier Saunders, 2011.

[16] Cheng CE, Friedlander SF. Infantile hemangiomas, complications and treatments. Semin Cutan Med Surg. 2016; 35: 108116.

[17] Drolet BA, Frommelt PC, Chamlin SL, et al. Initiation and use of propranolol for infantile hemangioma: report of a consensus conference. Pediatrics 2013; 131: 128-140.

[18] Janmohamed SR, de Waard-van der Spek FB, Madern GC, et al. Scoring the proliferative activity of haemangioma of infancy: the Haemangioma Activity Score (HAS). Clin Exp Dermatol. 2011; 36: 715-723.

[19] Haggstrom AN, Beaumont JL, Lai JS, et al. Measuring the severity of infantile hemangiomas: instrument development and reliability. Arch Dermatol. 2012; 148: 197-202.

[20] Léauté-Labrèze C, Dumas de la Roque E, Hubiche T, et al. Propranolol for severe hemangiomas of infancy. $\mathrm{N}$ Engl J Med. 2008; 358: 2649-2651.

[21] Léauté-Labrèze C, Hoeger P, Mazereeuw-Hautier J, et al. A randomized, controlled trial of oral propranolol in infantile hemangioma. N Engl J Med. 2015; 372: 735-746.
[22] Léauté-Labrèze C, Boccara $\mathrm{O}$, Degrugillier-Chopinet $\mathrm{C}$, et al. Safety of oral propranolol for the treatment of infantile hemangioma: A systematic review. Pediatrics 2016; 138: pii: e20160353.

[23] Chinnadurai S, Fonnesbeck C, Snyder KM, et al. Pharmacologic interventions for infantile hemangioma: A meta-analysis. Pediatrics 2016; 138: e20153896.

[24] Solymosi Á, Csitos Á, Tasnádi G, et al. Treatment with non-selective beta blockers in infantile capillary haemangiomas. [Nem szelektív béta-blokkolók alkalmazása infantilis kapilláris haemangiomákban.] Bőrgyógy Vener Szle. 2010; 86: 51-55. [Hungarian]

[25] Katona G, Csákányi Z, Gács E, et al. Propranolol for infantile haemangioma: striking effect in the first weeks. Int J Pediatr Otorhinolaryngol. 2012; 76: 1746-1750.

[26] Világos E, Bihari Nagy S, Harangi F. Systemic propanolol therapy in children with deep infantile hemangioma. [Subcutan infantilis haemangioma szisztémás propanolol kezelése.] Gyermekgyógyászat 2016; 67: 147-149. [Hungarian]

[27] Greenberger S, Bischoff J. Infantile hemangioma-mechanism(s) of drug action on a vascular tumor. Cold Spring Harb Perspect Med. 2011; 1: a006460.

[28] Smithson SL, Rademaker M, Adams S, et al. Consensus statement for the treatment of infantile haemangiomas with propranolol. Australas J Dermatol. 2017; 58: 155-159.

[29] Ovadia SA, Landy DC, Cohen ER, et al. Local administration of beta-blockers for infantile hemangiomas: a systematic review and meta-analysis. Ann Plast Surg. 2015; 74: 256-262.

[30] Csoma Z, Meszes A, Abraham R, et al. Birth marks and neonatal skin disorders. From angel kiss to epidermolysis bullosa. [Születési jegyek, újszülöttkori bőrelváltozások. Az angyalcsóktól az epidermolysis bullosáig.] Orv Hetil. 2014; 155: 500-508. [Hungarian]

(Csoma Zsanett Renáta dr., Szeged, Korányi fasor 6., 6720 e-mail: csoma.zsanett@med.u-szeged.hu)

\section{"Vulpes pilum mutat, non mores." (A róka megváltoztatja a szőrét, de nem a természetét.)}

